\title{
The complete genome sequences of Erythroxylum coca and Erythroxylum novogranatense
}

\author{
Dawson White \\ Field Museum \\ Lyndel Meinhardt \\ ARS/USDA \\ Bryan Bailey \\ ARS/USDA \\ Stacy Pirro ( $\square$ info@iridiangenomes.org ) \\ IRIDIAN GENOMES
}

\section{Data Note}

Keywords: Erythroxylum coca, Erythroxylum novogranatense, genome, assembly

Posted Date: January 5th, 2022

DOI: https://doi.org/10.21203/rs.3.rs-1221358/v1

License: (9) This work is licensed under a Creative Commons Attribution 4.0 International License.

Read Full License 


\title{
The complete genome sequences of Erythroxylum coca and Erythroxylum novogranatense
}

\author{
Dawson White ${ }^{1}$, Lyndel Meinhardt ${ }^{2}$, Bryan Bailey², Stacy Pirro²
}

${ }^{1}$ Grainger Bioinformatics Center, Science and Education Department, Field Museum. 1400 S. DuSable Lake Shore Dr., Chicago, IL 60605

${ }^{2}$ ARS/USDA, Beltsville, MD, 20705

${ }^{3}$ Iridian Genomes, Bethesda, MD , 20817

Keywords: Erythroxylum coca, Erythroxylum novogranatense, genome, assembly

\section{Abstract:}

The flowering plant genus Erythroxylum contains approximately 300 species, including the economically and socially consequential crops called coca. We present the genome sequences of Erythroxylum coca and $E$. novogranatense, two cultigens produced for medicinal and quotidian use in the Andes and Amazon regions of South America, as well as the international cocaine industry. Sequencing was performed on an Illumina X-Ten platform, and reads were assembled by a de novo method followed by finishing via comparison with several species from the same genus. The BioProject, raw and assembled data can be accessed in GenBank for E. coca (PRJNA676123; JAJMLV000000000) and E. novogranatense (PRJNA675212; JAJKBF000000000).

\section{Introduction:}

The leaves of the coca plant have been used as a medicine and mild stimulant in South America for over 8,000 years (Plowman, 1984; Dillehay et al, 2010). In more recent history, few plants have had such farreaching effects on human health and international relations (Restrepo et al, 2019). Coca crops produce the alkaloid cocaine: a natural insecticide (Nathanson et al, 1993), Western medicine's first local anesthetic, and a controlled narcotic whose supply chains and illicit international markets have caused decades of social disaster.

Coca is classified into two species, Erythroxylum coca and E. novogranatense (Erythroxylaceae, Malpighiales), each with two taxonomic varieties. These two species are found only in cultivation, having resulted from independent origins of domestication from the wild E. gracilipes (White et al, 2021).

The two varieties used in this study, E. coca var. ipadu Plowman, known as Amazonian coca, and E. novogranatense var. truxillense (Rusby) Plowman, known as Trujillo coca, are regionally distinct crops. Erythroxylum coca var. ipadu is a cultivated by indigenous groups in the lowland Amazon basin of Colombia, Brazil, and Perú. Erythroxylum novogranatense var. truxillense is grown primarily in the dry valleys of northwestern Perú and is exported as a flavoring agent of Coca Cola ${ }^{\circledR}$. These taxa have been crossed to produce improved hybrid varieties for the cocaine market, which are currently grown in southern Colombia and possibly southern Mexico (Casale, 2014; Rodriguez, 2015).

Complete genome sequences for E. coca var. ipadu and E. novogranatense var. truxillense will provide insight into the origins, evolution, and modern breeding patterns of coca crops, as well as the of the cocaine biosynthesis pathway. 


\section{Methods:}

DNA from each species was provided by USDA/ARS Sustainable Perennial Crops Laboratory for use in this study.

Sequencing libraries were constructed with the Illumina TruSeq kit using standard protocols for the $2 \times 150$ bp format. Sequencing was performed on an Illumina X-Ten platform.

Raw, paired-end sequence data was trimmed of adapter sequence and low-quality regions using Trimmomatic (Bolger et al, 2014). Genome preassemblies were constructed using SPAdes (Bankevich, 2012), and finished with Zanfona (Kieras et al, 2021.)

\section{Results:}

The results of genome assemblies are as follows:

\begin{tabular}{|l|l|l|l|}
\hline specimen & accession & genome size & N50 \\
\hline E. coca var. ipadu & JAJMLV000000000 & $584,059,212$ & $3,914,021$ \\
\hline E. novogranatense var. truxillense & JAJKBF000000000 & $573,212,218$ & $5,183,633$ \\
\hline
\end{tabular}

\section{Acknowledgements:}

Dawson White is supported by an NSF Postdoctoral Fellowship in Biology, award number 2010821.

\section{References:}

Bankevich, A, et al. "SPAdes: a new genome assembly algorithm and its applications to single-cell sequencing." Journal of computational biology: a journal of computational molecular cell biology vol. 19,5 (2012): 455-77. doi:10.1089/cmb.2012.0021

Bolger AM, Lohse M, Usadel B. Trimmomatic: A flexible trimmer for Illumina Sequence Data. Bioinformatics. 2014;30(15):2114-20. doi:10.1093/bioinformatics/btu170

Casale JF, Mallette JR, Jones LM. 2014. Chemosystematic identification of fifteen new cocaine-bearing Erythroxylum cultigens grown in Colombia for illicit cocaine production. Forensic Science International 237: 30-39.

Dillehay TD, Rossen J, Ugent D, Karathanasis A, Vásquez V, Netherly PJ. Early Holocene Coca Chewing In Northern Peru. Antiquity. 2010;84:939-953. doi: 10.1017/S0003598X00067004.

Kieras M, Peterson R, O'Neill K, Pirro S. 2021. ZANFONA, a genome finishing process for short read assemblies. https://github.com/zanfona734/zanfona. DOI: https://zenodo.org/record/5748239. 
Nathanson JA, Hunnicutt EJ, Kantham L, Scavone C. 1993. Cocaine as a naturally occurring insecticide. Proceedings of the National Academy of Sciences of the United States of America 90: 9645-9648.

Plowman T. The Ethnobotany of Coca (Erythroxylum spp., Erythroxylaceae) Repos. Inst. CEDRO. 1984

Restrepo, DA et al. "Erythroxylum in Focus: An Interdisciplinary Review of an Overlooked Genus." Molecules (Basel, Switzerland) vol. 24,20 3788. 21 Oct. 2019, doi:10.3390/molecules24203788

Rodríguez Zapata FV. 2015. Genome size and descriptors of leaf morphology as indicators of hybridization in colombian cultigens of coca Erythroxylum spp. Thesis, Universidad de los Andes. 42 pp.

White DM, Huang J-P, Orlando A J-M, Madriñán S, Ree RH, Mason-Gamer RJ. 2021. The Origins of Coca: Museum Genomics Reveals Multiple Independent Domestications from Progenitor Erythroxylum gracilipes. Systematic Biology 70: 1-13. 